Along with this report should go the statement that out of these appropriations sufficient was saved to add $\$ 6,465$ to the city's fixed capital and enough of the revenue was saved to add by special appropriations $\$ 9,872.49$.

All this has come to pass through a concentration of power and responsibility accomplished by the ordinance creating the office of municipal business manager. This officer's power is complete until a departmental committee unanimously appeals from him and the council sustains its appeal. No action of the kind has ever been taken or suggested.

\title{
CHECKS ON CONCENTRATION IN MODERN CHARTERS
}

\author{
BY DR. CHARLES FREMONT TAYLOR ${ }^{1}$ \\ Philadelphia
}

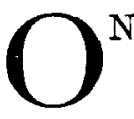

$\mathrm{NE}$ of the most important of the numerous worthy and useful accomplishments of the National Municipal League has been its influence on and helpfulness in city charter making in this country. At its recent annual meeting in Baltimore, this was one of the most important topics discussed; and it is a proof of the progressiveness of the league that after thorough discussion, the dominant opinion of the experts there assembled was that the "commission manager" plan of charter is the best in sight at the present time. However, the time limit for discussion expired just as the subject of checks was reached; and the present writer has been asked to take up this part of the subject, and also to give his views on two notable books that have recently appeared on charters and city government.

As the chief and most effective checks on the city manager plan of city government, as well as upon all other plans of either city or state government, are the initiative, referendum and recall, these will be given prominence in this presentation.

One of the most helpful books to charter committees that the writer has seen is "Applied City Government,"' by Herman G. James, J.D., Ph.D., associate professor of government and director of the bureau of municipal research and reference at the University of Texas. There is not a superfluous word in this book. It is a marvel of clear analysis and terse expression.

The formation of a charter is taken up step by step, and after each section of the proposed model charter is explained, it is put into terse and simple words and is printed in italic letters. Thus a model charter is

1 Editor of Equity and Medical World.

2 Published by Harper \& Brothers, New York, 1914. Price 75 cents. 
built up, article by article, so that, when a committee has finished the book, the italic portions of the book can be merely put together, and a model charter will be had. The writer knows of no other book on this subject on so simple and practical a plan.

The powers (article I) are expressed in these simple but comprehensive words: "and shall possess all powers consistent with the laws and constitution of the state of . . . " Thus in this simple manner, every question as to powers is at once limited only by the state laws and constitution. In the explanatory matter preceding he says that "an enumeration of powers will be construed to exclude powers not enumerated." The above brief statement, in italics, embraces all of home rule that any city in a given state can possess.

The model charter thus built up is short, consisting of only seven articles, and the articles as a rule are short and very exact in their expression. The author advocates the preferential ballot (Grand Junction plan), which he explains and illustrates clearly and includes in his model charter. He also explains proportional representation, but does not include it in the charter.

As to the form of government, he boldly adopts the commission form as modified by the city manager plan, though he seems to prefer the term mayor to city manager as applying to the chief administrative officer of the city. The commissioners shall serve without pay. The mayor (or city manager) shall be chosen by the commission without limit as to previous residence; this officer to be selected for his administrative qualifications for an indefinite term. He "shall be responsible to the governing body of the city for the proper administration of all the affairs of the city."

Sufficient has been said to indicate that this book presents the best and latest opinions concerning city charters, with (regretfully) an important exception which we will take up later under the head of checks.

Now let us take a peep into the other book: "Municipal Charters," 3 by Nathan Matthews, LL.D., mayor of Boston 1891-95, chairman of Boston finance commission 1907-09, lecturer on municipal government in Harvard University.

This is a scholarly book of the old school. These two books show vividly the difference in their point of view between Boston and Texas. The first part of the book (93 pages) deals with "essentials of an American city charter." Then follow charter drafts. The first one, along the lines of the old ideas, consists of 63 very full pages. Charter $B$, the commission type, would modify the first charter according to 10 pages of omissions, substitutions, etc. Part III of the book consists of 26 pages of notes to the charter drafts.

The author's conservatism is marked, in comparison with our Texas

${ }^{3}$ Published by Harvard University Press, 1914. Price $\$ 2.00$ net. 
author. He strongly favors the "responsible executive type" (page 14) of city government. The following sentence, quoted from page 15, sums up his ideal of city government:

"The type of charter best adapted to the case would therefore seem to be the responsible executive type with a single small legislative board or council, with such checks and balances as will prevent the grosser forms of extravagences and corruption, and with such a concentration of the several powers of the city government that at each succeeding election the voters may have no difficulty in determining who is and who is not responsible for what has been done or left undone."

It is surprising to the up-to-date student that the author would admit no possibility of recall, but "at each succeeding election" the voters may determine "who is and who is not responsible for what may have been done or left undone"! No check upon officers except the regular elections, and as we shall see later, no check upon what the officers may do! This is the plan that has always pleased the "predatory interests" and their creatures, the politicians.

Publicity has long been advocated and depended upon as a check to misgovernment and corruption in city government. No "cure" has so many failures to its credit. This remedy should be continued, of course. We should not give up anything in which there is any good at all; but we should recognize its weakness, and add checks that really do check.

Ex-mayor Matthews, as representing the conservative type of thought, favors a unicameral legislative body of small numbers. Thus we see that even the conservatives are now demanding the concentration of power in few hands. Along with this must go the possibility of checks on such concentrated power, to be used only in case of need.

This principle is so reasonable and necessary that very few oppose it. The check universally held by private employers upon their employees is the possibility of discharge. The public should have the same power of control of the public's employees. This is the recall. As we shall see later, this power is extensively held by cities and even by states, and it has not been abused. It has been used to excellent purpose, even the mere existence of this power exercising a salutary influence upon public officers.

A public officer, however, may do much harm before he could possibly be recalled; and he may be negatively good, but leave many important things undone. By the referendum it is possible for the voters to effectively check any undesirable ordinance; and by the initiative it is possible for the voters to propose and enact ordinances desired by them but neglected or opposed by their official (supposed) representatives. Thus faulty representation is remedied. And that is the only purpose of the initiative and referendum. They are not presented as a substitute for representative government, but only as a corrective of false representation. 
Now to take up Professor James' book again: Among its many excellencies we regret to find a reactionary note. Concerning the initiative and referendum let us say the good things first. Here is section I of article VII (pages 92 and 93 ):

Every issue of bonds authorized by the governing body of the city, under the limitations herein prescribed, and every grant of a franchise for the operation of a public utility, under the following limitations, shall, before becoming effective, be submitted to a vote of the people for ratification. Such ratification shall occur at a special election held for that purpose unless a regular election occurs within ninety days of the date of passing the resolution authorizing the bond issue or the granting of the franchise, in which case the question shall be submitted at such election. In either case a majority of the votes cast on the question shall be necessary and sufficient to make the proposed measure effective.

Beyond this, which, however, is a very important exception, Professor James is hopelessly conservative concerning these important checks on concentrated government. For either the initiative or referendum he would make the astonishing requirement of 35 per cent, not of the votes cast at the previous election, but of the qualificd voters (that is, whether they voted at the preceding election or not). And for the recall he would make the same extreme requirement.

Turning again to Ex-mayor Matthews' book: He would tolerate the referendum on licenses for the sale of intoxicating liquors, the issue of loans for particular purposes, the establishing of public gas, water, electric lighting and similar undertakings, etc., and it is to be invoked presumably by the council, as he distinctly and emphatically opposes the initiative, referendum or recall on petition by the voters. Thus this book, though new, takes a place among the antiquated works on municipal government.

Considering Ex-mayor Matthews as hopeless, and assuming that the readers of this progressive magazine recognize the fact that concentrated power may become dangerous unless it is possible to use checks when occasion may arise, and as it is very probable that the readers of this magazine and many charter committees will be attracted to Professor James' book, let us address ourselves to the extreme and unreasonable percentages he would require for invoking the initiative, referendum and recal!.

The writer has now before him the charters of 37 initiative, referendum and recall cities, and 27 general state laws concerning the use of the initiative, referendum and recall in cities. Not one makes the extreme requirements advocated by Professor James. Wilmington, North Carolina, comes the nearest, requiring 35 per cent, not of the registered voters, but of the vote cast at the last preceding general election. And while it would require 35 per cent for the initiative special election, yet it would allow an initiative on 10 per cent, to be voted on at the next general elec- 
tion. This is the closest we can come to Professor James' figures in actual practice, and it stands alone, though its requirements are much easier than those of Professor James.

In practice, the recall percentages are the highest, ranging from 15 per cent (Sacramento, California, only 10 per cent-and no harm done) to 35 per cent. Many are 15 per cent, many 20 per cent and many 25 per cent-very few higher. The initiative and referendum percentages run distinctly lower. There are many 5 per cent, and many 10 per cent. Some run higher. The higher percentages are usually for special elections.

Now how have these worked in practice? Details may be seen in "Municipal Initiative, Referendum and Recall in Practice," by the present writer in October, 1914, issue of this magazine. ${ }^{4}$ But the following brief statement may be made here:

In this country there are nearly 400 municipalities that have the commission form of government; and nearly all of them have the initiative, referendum or recall, and some municipalities not under the commission form of government have these powers. A majority (at least 200) have all three of these powers, while some have the initiative and referendum without the recall, etc. Of all these municipalities, and for all the time they have possessed these powers, a nation-wide investigation discovered that only 31 had used the initiative, 26 the referendum and 33 the recall. Further, 35 attempts to invoke the recall have been made, but failed on account of the promoters not being able to get a sufficient number of signatures. This indicates that the securing of recall signatures is not as easy as some theorists seem to believe. Of the 33 recall elections actually held, 20 resulted in recall and 13 resulted in re-election of the official sought to be recalled.

In examining the uses of the initiative, referendum and recall in the various cities of the country, we do not find any indication of the fact that those cities which have the lowest percentages have used these powers the most frequently. In fact, many whose requirements are the lowest have not used these powers at all. Among those which have used these powers the most frequently can be found those which require the highest percentages. For example, Dallas, Texas, has made the most frequent and the most successful use of the recall among all the cities that have the recall, yet its recall requirement is 35 per cent, the highest percentage given, yet not quite as high as that recommended by Professor James, as he recommends 35 per cent of the entire electorate, whereas Dallas, Texas, requires " 35 per cent of the entire vote cast for candidates for the office of mayor on the final ballot at the last preceding general municipal election." Hence it seems that when there is occasion to invoke these powers, they will be invoked even though the conditions are difficult; and easy condi-

4 Vol. iii, p. 693. 
tions do not cause the undue use of these powers. Here we have facts and experience favoring low percentages. Facts and experience prove that low percentages do not lead to abuse of these powers.

The above results show a striking conservatism on the part of the voters. They do not abuse these enlarged powers, but they use them to good purpose when there is occasion. The corruption that a few years ago made municipal government in America notorious the world over would have been impossible if the voters of all municipalities had possessed the initiative, referendum and recall.

The old-fashioned "checks and balances" consisting chiefly of distribution of powers and division of responsibilities did not check, and the "balances" were seen chiefly in the bank accounts of "boodlers" who were permitted to use the powers of city government for their own selfish aggrandizement. Publicity was later added as a check, and we wish to preserve and extend it, but it has not been an effective check.

The old-fashioned "checks and balances," the division of powers and distribution of responsibilities, do not check. They permit the intrusion of selfish interests in the government and prevent the adequate protection of the public interests. We see the need of discontinuing the "balances," and of concentrating the powers and responsibilities. This is the only way to increase efficiency. But concentrated powers are dangerous without the possibility of control outside the few hands into which great power has been concentrated. Where is the most rational place in which to lodge this possible control? There can be but one answer: the electorate. And the initiative, referendum and recall are the best methods yet devised in which to exercise this control.

These, then, are the checks par excellence. They do not obtrude except when needed. They do not interfere with efficiency, yet they insure faithfulness and honesty. They are admirable in theory, and they have proven to be safe and effective in practice.

There is one thing more that may possibly be construed as a check. It is proportional representation. It can be construed as a check on the theory that a representative body chosen by a method that will place in that body representatives of every considerable class or group in the electorate, approximately according to the numbers of each, will be more likely to represent the electorate truly and satisfactorily than a body not so made up. The theory is good, and the practice will doubtless prove the theory. 